\title{
Golden flaxseed and its byproducts in beef patties: physico-chemical evaluation and fatty acid profile
}

\author{
Linhaça dourada e subprodutos em hambúrgueres: avaliação físico-química e \\ perfil de ácidos graxos
}

\section{Daiana Novello ${ }^{\mathrm{I}}$ Marise Aparecida Rodrigues Pollonio ${ }^{\mathrm{II}}$}

\section{ABSTRACT}

Flaxseed application in meat and meat products by adding not flesh ingredients has not yet been properly assessed. This technology strategy, if well optimized, could substantially improve the nutritional value of meat products and promote healthy appeals consistent. Knowing that, this study aimed to evaluate the effect of adding golden flaxseed oil, or flour, or seed in the physicochemical properties and fatty acid profile of beef patties. Beef patties were prepared with $5.0 \%$ of oil (FO), or flour (FF), or seed (FS), plus a control formulation (FC). For raw products containing flaxseed, the moisture content (74.22 to 68.61\%) was decreased

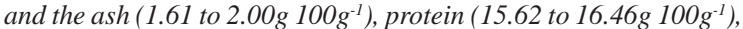

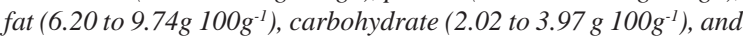

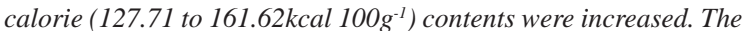
raw and grilled samples containing golden flaxseed had increased beneficial omega-3 (n-3) fatty acids (0.85 a 2.98g 100 $\mathrm{g}^{-1}$ ), a decreased $n-6 / n-3$ ratio $(<1)$, and an increased polyunsaturated/ saturated ratio (>0.50), thus improving the nutritional profile.

Key words: Linum Usitatissimum Linaceae, linseed, nutritive value, beef.

\section{RESUMO}

A aplicação de linhaça em carne e produtos cárneos através da adição como ingrediente não-cárneo não foi ainda devidamente avaliada. Essa estratégia tecnológica, se bem otimizada, poderia melhorar substancialmente o valor nutricional de produtos cárneos e promover apelos saudáveis consistentes. Sabendo disso, este estudo teve como objetivo avaliar o efeito da adição de óleo, ou farinha, ou semente de linhaça dourada sobre as propriedades físico-químicas e o perfil de ácidos graxos de hambúrgueres bovinos. Os hambúrgueres foram preparados com $5,0 \%$ de óleo (OL), farinha (FL), ou de semente (SL), além de uma formulação controle (FC). Para os produtos crus contendo linhaça, o teor de umidade $(74,22$ a 68,61\%) diminuiu e os teores de cinzas (1,61 a 2,00g $\left.100 \mathrm{~g}^{-1}\right)$, proteínas (15,62 a 16,46g $\left.100 \mathrm{~g}^{-1}\right)$,

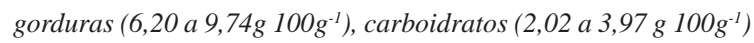
e calorias $\left(127,71\right.$ a 161,62 kcal 100 $\left.\mathrm{g}^{-1}\right)$ aumentaram. As amostras cruas e cozidas contendo linhaça dourada tiveram um aumento benéfico de ácidos graxos ômega-3 (n-3) (0,85 a 2,98g 100g-1), e uma redução da relação n-6/n-3 (<1), além de um aumento da relação poli-insaturados/saturados ( $>0,50)$, melhorando assim o perfil nutricional.

Palavras-chave: Linum Usitatissimum Linaceae, linhaça, valor nutricional, carne.

\section{INTRODUCTION}

Meat and meat derivatives are some of the most important sources of dietary fat in Brazil. However, due to their saturated fat and cholesterol content, consumption of these products is associated with cardiovascular diseases, certain types of cancer, and obesity (FERNÁNDEZ-GINÉS et al., 2005).

Hamburgers are especially important for the fast food industry (ÖZKAN et al., 2004). Because they are widely accepted by consumers, functional ingredients can be added to produce lower calorie foods, keeping its flavor (FERNÁNDEZGINÉS et al., 2005). Thus, altering the lipid content of these products and modifying the omega-3 (n-3) polyunsaturated fatty acid (PUFA) profile can help to improve their nutritional quality (ANSORENA \& ASTIASARÁN, 2004) and reduce the risk of chronic diseases in the population (FERNÁNDEZ-GINÉS et al., 2005).

\footnotetext{
'Departamento de Nutrição, Universidade Estadual do Centro-Oeste (UNICENTRO), CP 3010, 85040-080, Guarapuava, PR, Brasil. E-mail: nutridai@hotmail.com. Autor para correspondência.

IIDepartamento de Tecnologia de Alimentos, Universidade Estadual de Campinas (UNICAMP), Campinas, SP, Brasil. Received 10.05.12 Approved 04.04.13 Returned by the author 07.03.13 CR-2012-0946.R2
} 
Flaxseed is an oilseed that contains large amount of oil, dietary fiber and protein. Its composition on average is $41 \%$ fat, $28 \%$ total dietary fiber, $20 \%$ protein, $7.7 \%$ moisture, $3.5 \%$ ash and $1 \%$ simple sugars. The amount of fat in flaxseed can vary from $34-47 \%$ depending on location and growing environmental conditions (MORRIS \& VAISEYGENSER, 2003; FITZPATRICK, 2006).

Flaxseed, principally seed and flour, has been consumed for centuries, both because of its taste and for its nutritional features. Greater concern over health and wider knowledge about the functional properties of flaxseed and its derivatives has dramatically increased flaxseed consumption. Because of the n-3 fatty acids, lignans, and dietary fiber in flaxseed, many specific benefits are associated with flaxseed consumption (WILKES, 2007).

This food has been correlated with a reduced risk of cardiovascular disease, hyperlipidemia, and cancer (ABDEL-RAHMAN et al., 2009) besides preventing menopausal symptoms and osteoporosis (KIM \& ILICH, 2011), among others.

However, few studies have reported the development of meat products enriched with n-3 fatty acids (DELGADO-PANDO et al., 2012; MARTÍNEZ et al., 2012), and no study has reported the use of golden flaxseed seed or flour in beef patties. Knowing that, the objective of this research was to develop beef patties added by golden flaxseed oil, or flour or seed and evaluate their physico-chemical composition and fatty acid profile, improving the nutritional characteristics of the products.

\section{MATERIALS AND METHODS}

\section{Materials}

Thirteen kilograms of chuck meat and thirteen kilograms of blade steak (code B 2211 and code A 2100, respectively, ABIEC, 2006) were purchased from commercial frozen meat storage plants in the city of Campinas, SP, Brazil. All external fat and the adjacent muscles were removed.

It was evaluated standard beef patties and those that were mixed with $5.0 \%$ flaxseed oil, or flour, or seed. These formulations were previously selected by sensory evaluations in a previous study.

Selected golden flaxseed (Linum Usitatissimum L.) and its derivatives (flour and oil) from the same widely marketed commercial brand were obtained from specialized suppliers in the city of Campinas, SP, Brazil. Table 1 describes the beef patty formulations.

Preparation of beef patties

Meat selected at $4{ }^{\circ} \mathrm{C}$ was ground in a meat grinder (C.A.F machines. Model 10, Rio Claro-SP, Brazil) equipped with a $3 \mathrm{~mm}$ grinding disk. It was used approximately $11 \mathrm{~kg}$ of meat (both cuts) for each of the four formulations. The following ingredients were added to meat in a food processor (Filizola, Super Cutter, model Sire, São Paulo-SP, Brazil) in the following order: half of ice, seasonings (onion and garlic powder), sodium erythorbate, the second half of ice, salt, carrageenan, maltodextrin, palm oil, and the appropriate type of golden flaxseed additive (oil, flour, or seed). After homogenization, the formulation was packaged in low-density polyethylene (LDPE)

Table 1 - Beef patty formulations added with golden flaxseed oil, or flour, or seed.

\begin{tabular}{|c|c|c|c|c|}
\hline \multirow{2}{*}{ Ingredient } & \multirow[b]{2}{*}{$\mathrm{FC}$} & \multirow[b]{2}{*}{ FO } & \multirow[b]{2}{*}{$\mathrm{FF}$} & \multirow[b]{2}{*}{ FS } \\
\hline & & & & \\
\hline Meat & 75.85 & 70.85 & 70.85 & 70.85 \\
\hline Ice flakes & 15.00 & 15.00 & 15.00 & 15.00 \\
\hline Palm oil & 5.00 & 5.00 & 5.00 & 5.00 \\
\hline Golden flaxseed oil & - & 5.00 & - & - \\
\hline Golden flaxseed flour & - & - & 5.00 & - \\
\hline Golden flaxseed seed & - & - & - & 5.00 \\
\hline Maltodextrin & 1.80 & 1.80 & 1.80 & 1.80 \\
\hline Salt & 1.50 & 1.50 & 1.50 & 1.50 \\
\hline Carrageenan & 0.20 & 0.20 & 0.20 & 0.20 \\
\hline Onion powder & 0.30 & 0.30 & 0.30 & 0.30 \\
\hline Garlic powder & 0.30 & 0.30 & 0.30 & 0.30 \\
\hline Sodium erythorbate & 0.05 & 0.05 & 0.05 & 0.05 \\
\hline
\end{tabular}

FC: control; FO: 5.0\% golden flaxseed oil; FF: 5.0\% golden flaxseed flour; FS: 5.0\% golden flaxseed seed. 
plastic bags and stored in a freezer $\left(0^{\circ} \mathrm{C}\right.$ to $\left.-1^{\circ} \mathrm{C}\right)$ for approximately 1 hour to facilitate molding. The mixture was then molded into units (130-140 beef patties on average) of approximately $110 \mathrm{~g}$ and $10 \mathrm{~cm}$ in diameter using a manual patty maker (Picelli, HP112/130 model, Rio Claro-SP, Brazil) and frozen in a cold storage room $\left(-18^{\circ} \mathrm{C}\right)$. Frozen samples were packed in LDPE plastic bags, sealed with adhesive tape, and stored in cartons (containing 6 beef patties) that were labeled and stored in a freezer $\left(-18^{\circ} \mathrm{C}\right)$.

\section{Cooking of beef patties}

Frozen beef patties were grilled at $200^{\circ} \mathrm{C}$ on an electrically heated clamshell grill (George Foreman Lean Mean Fat Reducing Grilling Machine Jumbo size, Model GR38SIL, Madison-Wisconsin, USA). The internal temperature of beef patty was controlled by a digital thermometer B 345 (Micronal, São Paulo-SP, Brazil) with a connected thermocouple until the center temperature reached $75^{\circ} \mathrm{C}$ (ARISSETO \& POLLONIO, 2005). The cooking time was 8-10 minutes on average.

\section{Physico-chemical evaluation}

Moisture content (raw and grilled beef patties), protein ( $\mathrm{N}$ x 6.25) (raw beef patties), and ash (raw and grilled beef patties) were evaluated according to the methods described by the Association of Official Analytical Chemists (AOAC, 1980). The lipid content (raw and grilled beef patties) was measured by the method of BLIGH \& DYER (1959). Carbohydrate contents were calculated by difference (raw beef patties). Total energy (kcal) estimates in raw beef patties were calculated based on a $100 \mathrm{~g}$ sample using water exact values for fat $\left(9.03 \mathrm{kcal} \mathrm{g}^{-1}\right)$, protein $\left(4.27 \mathrm{kcal} \mathrm{g}^{-1}\right)$, and carbohydrate $\left(3.82 \mathrm{kcal} \mathrm{g}^{-1}\right)$ (MERRILL \& WATT, 1973). The $\mathrm{pH}$ values (raw and grilled beef patties) were measured with a digital potentiometer (model MP125 pH Meter, Mettler Toledo, Florida, USA), equipped with a combination pH electrode (Sensorex, S175CD Spear Tip model, Garden Grove-CA, USA) calibrated in buffers at $\mathrm{pH}$ 4.01 and 7.00 (Mettler Toledo, Florida, USA) at $25^{\circ} \mathrm{C}$.

Fatty acid composition

For the preparation of methyl esters, samples of raw and grilled beef patties (time 0) were initially processed by cold method lipid extraction (BLIGH \& DYER, 1959). Each lipid sample were saponified and esterified in triplicate as described by HARTMANN \& LAGO (1973). The fatty acid profile was determined by high-resolution gas chromatography (AOCS, 2004). Saturated fatty acids (SFA), monounsaturated fatty acids (MUFA), and PUFA were individually evaluated. Samples were analyzed on a Gas Chromatograph (Agilent, 6850 Series GC System model, Santa Clara-CA, USA) using a DB-23 Agilent capillary column (50\% cyanopropyl - methylpolysiloxane) with the following dimensions: $60 \mathrm{~m}, \varnothing$ int: $0.25 \mathrm{~mm}, 0.25 \mu \mathrm{m}$ film. The operating conditions of the chromatograph were as

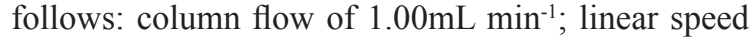
of $24 \mathrm{~cm} \mathrm{~s}^{-1}$; detector temperature at $280^{\circ} \mathrm{C}$; injector temperature of $250^{\circ} \mathrm{C}$; oven temperature initially set to $110^{\circ} \mathrm{C}$ for 5 minutes, followed by a gradient of 110 $215^{\circ} \mathrm{C}$ at $5^{\circ} \mathrm{C} \mathrm{min}^{-1}$ and then $215^{\circ} \mathrm{C}$ for 24 minutes. Helium was used as the carrier gas, and a volume of $1 \mu \mathrm{L}$ of sample aliquot was injected in the apparatus. Fatty acids were identified by comparing the sample peak retention times with those of standards. The results were expressed as \% of area and converted to g $100 \mathrm{~g}^{-1}$ using a conversion factor $(0.916)$ suitable for beef meat (HOLLAND et al., 1997).

\section{Statistical analysis}

Statistical analysis was performed by analysis of variance (ANOVA) followed by Tukey's post-hoc test to compare means at the $5 \%$ significance level using Statgraphics ${ }^{\circledR}$ Plus software, version 5.1.

\section{RESULTS AND DISCUSSION}

\section{Physico-chemical evaluation}

The physico-chemical evaluation of the four types of raw and grilled beef patties, is presented in table 2. In raw beef patties, the addition of 5.0\% golden flaxseed flour (FF) or seed (FS) increased the ash, protein, and carbohydrate contents. However, the addition of $5.0 \%$ golden flaxseed oil (FO) is the ingredient that more increased the lipid content $(\mathrm{P}<0.05)$, followed by the flour and seed. The control formulation (FC) showed the lowest lipid content and also increased the ash content in FF and FS samples. According to TRUCOM (2006), flaxseed and its derivatives are high in fat, which explains the increased lipid contents in FO, FF, and FS.

The addition of golden flaxseed flour, oil, and seed decreased the moisture content in raw and grilled beef patties $(\mathrm{P}<0.05)$, due to the increased amount of dry matter in the formulations. Similar results were obtained in beef patties with flaxseed flour (BILEK \& TURHAN, 2009), hazelnut layer (TURHAN et al., 2005) and textured soy protein (PASSOS \& KUAYE, 2002). 
Table 2 - Physico-chemical evaluation of raw and grilled beef patties added with golden flaxseed oil, or flour, or seed

\begin{tabular}{|c|c|c|c|c|}
\hline \multirow[t]{2}{*}{ Parameters } & $\mathrm{FC}$ & FO & $\mathrm{FF}$ & FS \\
\hline & Mean \pm SD & Mean \pm SD & Mean \pm SD & Mean \pm SD \\
\hline \multicolumn{5}{|l|}{ Raw product } \\
\hline Moisture (\%) & $74.22 \pm 0.04 \mathrm{a}$ & $71.02 \pm 0.18 \mathrm{~b}$ & $68.61 \pm 0.04 \mathrm{c}$ & $68.72 \pm 0.07 \mathrm{c}$ \\
\hline $\operatorname{Ash}\left(\mathrm{g} 100 \mathrm{~g}^{-1}\right)$ & $1.61 \pm 0.00 \mathrm{~b}$ & $1.64 \pm 0.03 \mathrm{~b}$ & $1.90 \pm 0.06 \mathrm{a}$ & $2.00 \pm 0.06 \mathrm{a}$ \\
\hline Fat $\left(g_{\left.100 g^{-1}\right)}\right.$ & $6.20 \pm 0.05 c$ & $9.74 \pm 0.08 \mathrm{a}$ & $8.81 \pm 0.02 b$ & $8.87 \pm 0.18 \mathrm{~b}$ \\
\hline Protein $\left(g_{\left.100 g^{-1}\right)}\right.$ & $15.95 \pm 0.03 \mathrm{~b}$ & $15.62 \pm 0.12 b$ & $16.64 \pm 0.06 \mathrm{a}$ & $16.46 \pm 0.08 \mathrm{a}$ \\
\hline 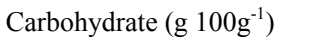 & $2.02 \pm 0.02 \mathrm{~b}$ & $1.98 \pm 0.06 \mathrm{~b}$ & $3.97 \pm 0.03 \mathrm{a}$ & $3.96 \pm 0.23 \mathrm{a}$ \\
\hline Energy value (kcal $100 \mathrm{~g}^{-1}$ ) & $127.71 \pm 0.44 \mathrm{c}$ & $158.11 \pm 1.05 b$ & $161.62 \pm 0.05 \mathrm{a}$ & $161.35 \pm 0.42 \mathrm{a}$ \\
\hline $\mathrm{pH}$ & $5.94 \pm 0.01 \mathrm{a}$ & $5.97 \pm 0.01 \mathrm{a}$ & $5.89 \pm 0.00 \mathrm{~b}$ & $5.89 \pm 0.01 \mathrm{~b}$ \\
\hline \multicolumn{5}{|l|}{ Grilled product } \\
\hline Moisture (\%) & $68.59 \pm 0.00 \mathrm{a}$ & $61.28 \pm 0.09 \mathrm{~d}$ & $64.44 \pm 0.06 b$ & $64.07 \pm 0.01 \mathrm{c}$ \\
\hline $\operatorname{Ash}\left(g_{100 g^{-1}}\right)$ & $2.07 \pm 0.03 \mathrm{~b}$ & $2.11 \pm 0.06 \mathrm{~b}$ & $2.23 \pm 0.13 \mathrm{a}$ & $2.29 \pm 0.09 \mathrm{a}$ \\
\hline Fat $\left(\mathrm{g} 100 \mathrm{~g}^{-1}\right)$ & $7.07 \pm 0.06 \mathrm{c}$ & $12.77 \pm 0.08 \mathrm{a}$ & $9.46 \pm 0.04 b$ & $9.41 \pm 0.08 b$ \\
\hline $\mathrm{pH}$ & $6.13 \pm 0.01 \mathrm{a}$ & $6.10 \pm 0.01 \mathrm{ab}$ & $6.04 \pm 0.02 b$ & $6.08 \pm 0.04 \mathrm{ab}$ \\
\hline
\end{tabular}

Different letters in row indicate significant differences by Tukey's test $(\mathrm{P}<0.05)$; Values are mean of three replicates; $S D$ : standard deviation; Carbohydrate: theoretical calculation; FC: control; FO: 5.0\% golden flaxseed oil; FF: 5.0\% golden flaxseed flour; FS: 5.0\% golden flaxseed seed.

During cooking, water loss occurred, increasing the concentration of certain components (ash and lipids), which is in agreement with TURHAN et al. (2007) and BILEK \& TURHAN (2009). Adding $5.0 \%$ golden flaxseed flour (FF) or seed (FS) reduced the $\mathrm{pH}$ of the raw samples, while in the grilled beef patties only $\mathrm{FF}$ showed lower $\mathrm{pH}$ than control $(\mathrm{P}<0.05)$. This finding was also in agreement with BILEK \& TURHAN (2009).

\section{Fatty acid composition}

The profile of fatty acids, SFA, MUFA, PUFA, and trans fat of raw and grilled beef patties with golden flaxseed and its byproducts, is shown in table 3 and 4, respectively. There was an increase in the total SFA content of raw and grilled beef patties in the formulation with $5.0 \%$ golden flaxseed oil $(\mathrm{P}<0.05)$, which correlates with higher SFA content

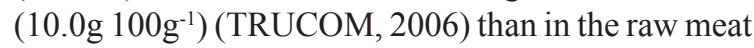
$\left(2{\left.\mathrm{~g} 100 \mathrm{~g}^{-1}\right)}\right.$ (TACO, 2011). In raw and grilled beef patties, the fatty acids that were observed in greatest quantities were C16:0 and C18:0, and the levels of these fatty acids were highest in treatment FO.

In general, FO had the highest individual and total MUFA increases in raw and grilled beef patties $(\mathrm{P}<0.05)$, followed by those containing 5.0\% golden flaxseed flour and seed $(\mathrm{P}>0.05)$. PUFA, linoleic, and $\alpha$-linolenic acid were observed in greater quantities in raw and grilled beef patties. In general, the evaluation of sample FO provided larger individual and total increases of PUFA $(\mathrm{P}<0.05)$, followed by $\mathrm{FF}$ and $\mathrm{FS}(\mathrm{P}>0.05)$. It was possible to significantly increase the amount of $n-3$ fatty acid C18:3 in raw beef patties (approximately 28 -fold by adding golden flaxseed flour and seed and 67-fold with the addition of golden flaxseed oil), which was in agreement with BILEK \& TURHAN (2009).

The DEPARTMENT OF HEALTH (1994) state that PUFA/SFA ratios below 0.4 are characteristic of an unhealthy diet and are associated with greater cardiovascular disease risk. The recommended ratio is between 1 and 1.5 (KANG et al., 2004; 2005), and values up to 4.8 are acceptable to assist in the treatment of some diseases (KANG et al., 2005). Furthermore, a $n-6 / n-3$ ratio of $4: 1$ or less is recommended as ideal for consumption (BARCELÓ-COBLIJN et al., 2003). However, according to BILEK \& TURHAN (2009), the effect of the $n-6 / n-3$ ratio is more significant than the PUFA/SFA ratio in terms of human nutrition.

In both raw and grilled samples, the n- $6 / n-3$ ratio of the control sample was the least favorable from a nutritional point of view $(\mathrm{P}<0.05)$. Because of the greater amount of n-3 fatty acids, FO presented the lowest value followed by FF and FS. These findings corroborate those reported by BILEK \& TURHAN (2009). As for PUFA/SFA, FC presented the least favorable ratio from a nutritional perspective, and FO had the best ratio $(\mathrm{P}<0.05)$.

In grilled beef patties, the addition of golden flaxseed oil increased the content of trans 
Table 3 - Profile fatty acids saturated, monounsaturated, polyunsaturated, and trans fat of raw beef patties ( $\mathrm{g}^{100 \mathrm{~g}^{-1}} \mathrm{of}$ product) added with golden flaxseed oil, or flour, or seed.

\begin{tabular}{|c|c|c|c|c|}
\hline \multirow{2}{*}{ Parameters } & \multirow[b]{2}{*}{$\mathrm{FC}$} & \multirow[b]{2}{*}{ FO } & \multirow[b]{2}{*}{$\mathrm{FF}$} & \multirow[b]{2}{*}{ FS } \\
\hline & & & & \\
\hline Raw product & Mean $\pm S D$ & Mean $\pm S D$ & Mean $\pm S D$ & Mean $\pm S D$ \\
\hline \multicolumn{5}{|l|}{ SFA } \\
\hline Lauric (C12:0) & $0.01 \pm 0.00 \mathrm{a}$ & $0.01 \pm 0.00 \mathrm{a}$ & $0.01 \pm 0.00 \mathrm{a}$ & $0.01 \pm 0.00 \mathrm{a}$ \\
\hline Myristic (C14:0) & $0.10 \pm 0.00 \mathrm{a}$ & $0.09 \pm 0.00 \mathrm{~b}$ & $0.09 \pm 0.00 \mathrm{~b}$ & $0.09 \pm 0.00 \mathrm{~b}$ \\
\hline Pentadecanoic (C15:0) & $0.01 \pm 0.00 \mathrm{a}$ & $0.01 \pm 0.00 \mathrm{a}$ & $0.01 \pm 0.00 \mathrm{a}$ & $0.01 \pm 0.00 \mathrm{a}$ \\
\hline Palmitic (C16:0) & $2.15 \pm 0.05 b$ & $2.32 \pm 0.07 \mathrm{a}$ & $2.21 \pm 0.03 \mathrm{ab}$ & $2.21 \pm 0.00 \mathrm{ab}$ \\
\hline Margaric (C17:0) & $0.04 \pm 0.00 \mathrm{a}$ & $0.04 \pm 0.00 \mathrm{a}$ & $0.04 \pm 0.00 \mathrm{a}$ & $0.04 \pm 0.00 \mathrm{a}$ \\
\hline Stearic (C18:0) & $0.67 \pm 0.02 b$ & $0.83 \pm 0.03 \mathrm{a}$ & $0.72 \pm 0.02 b$ & $0.72 \pm 0.02 b$ \\
\hline Arachidic (C20:0) & $0.02 \pm 0.00 \mathrm{~b}$ & $0.03 \pm 0.00 \mathrm{a}$ & $0.02 \pm 0.00 \mathrm{~b}$ & $0.02 \pm 0.00 \mathrm{~b}$ \\
\hline Behenic (C22:0) & $0.00 \pm 0.00 \mathrm{c}$ & $0.01 \pm 0.00 \mathrm{a}$ & $0.01 \pm 0.00 \mathrm{a}$ & $0.01 \pm 0.00 \mathrm{a}$ \\
\hline Lignoceric (C24:0) & $0.00 \pm 0.00 \mathrm{~b}$ & $0.01 \pm 0.00 \mathrm{a}$ & $0.01 \pm 0.00 \mathrm{a}$ & $0.01 \pm 0.00 \mathrm{a}$ \\
\hline Total & $3.00 \pm 0.08 \mathrm{~b}$ & $3.35 \pm 0.06 \mathrm{a}$ & $3.12 \pm 0.10 \mathrm{~b}$ & $3.12 \pm 0.02 b$ \\
\hline Percentage total $(\%)$ & 49.42 & 33.07 & 40.73 & 40.21 \\
\hline \multicolumn{5}{|l|}{ MUFA } \\
\hline Palmitoleic (C16:1 n-7) & $0.05 \pm 0.00 \mathrm{~b}$ & $0.06 \pm 0.00 \mathrm{a}$ & $0.05 \pm 0.00 \mathrm{~b}$ & $0.05 \pm 0.00 \mathrm{~b}$ \\
\hline Margaroleic (C17:1 n-7) & $0.02 \pm 0.00 \mathrm{a}$ & $0.02 \pm 0.00 \mathrm{a}$ & $0.02 \pm 0.00 \mathrm{a}$ & $0.02 \pm 0.00 \mathrm{a}$ \\
\hline Oleic (C18:1 n-9) & $2.43 \pm 0.07 \mathrm{c}$ & $3.33 \pm 0.10 \mathrm{a}$ & $2.83 \pm 0.12 b$ & $2.89 \pm 0.06 \mathrm{~b}$ \\
\hline Gadoleic (C20:1 n-9) & $0.01 \pm 0.00 \mathrm{a}$ & $0.01 \pm 0.00 \mathrm{a}$ & $0.01 \pm 0.00 \mathrm{a}$ & $0.01 \pm 0.00 \mathrm{a}$ \\
\hline Total & $2.51 \pm 0.07 \mathrm{c}$ & $3.42 \pm 0.10 \mathrm{a}$ & $2.91 \pm 0.09 \mathrm{~b}$ & $2.98 \pm 0.04 \mathrm{~b}$ \\
\hline Percentage total $(\%)$ & 41.35 & 33.76 & 37.99 & 38.40 \\
\hline \multicolumn{5}{|l|}{ PUFA } \\
\hline Linoleic (C18:2 n-6) & $0.52 \pm 0.00 \mathrm{c}$ & $1.33 \pm 0.04 \mathrm{a}$ & $0.77 \pm 0.03 b$ & $0.79 \pm 0.00 \mathrm{~b}$ \\
\hline$\alpha$-Linolenic (C18:3 n-3) & $0.03 \pm 0.00 \mathrm{c}$ & $2.02 \pm 0.00 \mathrm{a}$ & $0.85 \pm 0.02 b$ & $0.86 \pm 0.01 b$ \\
\hline Docosapentaenoic (DPA) (C22:5n-3) & $0.01 \pm 0.00 \mathrm{a}$ & $0.01 \pm 0.00 \mathrm{a}$ & $0.01 \pm 0.00 \mathrm{a}$ & $0.01 \pm 0.00 \mathrm{a}$ \\
\hline Total & $0.56 \pm 0.08 \mathrm{c}$ & $3.36 \pm 0.12 \mathrm{a}$ & $1.63 \pm 0.10 \mathrm{~b}$ & $1.66 \pm 0.09 \mathrm{~b}$ \\
\hline Percentage total $(\%)$ & 9.23 & 33.17 & 21.28 & 21.39 \\
\hline \multicolumn{5}{|l|}{ Ratios } \\
\hline$n-6 / n-3$ ratio & $13.00 \pm 0.07 \mathrm{a}$ & $0.66 \pm 0.02 \mathrm{c}$ & $0.90 \pm 0.01 b$ & $0.91 \pm 0.01 \mathrm{~b}$ \\
\hline PUFA/SFA ratio & $0.19 \pm 0.09 \mathrm{c}$ & $1.00 \pm 0.05 \mathrm{a}$ & $0.52 \pm 0.08 \mathrm{~b}$ & $0.53 \pm 0.06 \mathrm{~b}$ \\
\hline \multicolumn{5}{|l|}{ Trans } \\
\hline Elaidic (C18:1 trans 9) & $0.06 \pm 0.00 \mathrm{a}$ & $0.05 \pm 0.00 \mathrm{~b}$ & $0.05 \pm 0.00 \mathrm{~b}$ & $0.05 \pm 0.00 \mathrm{~b}$ \\
\hline Linolelaidic (C18:2 trans $\mathrm{t} 9, \mathrm{t} 12)$ & $0.02 \pm 0.00 \mathrm{a}$ & $0.02 \pm 0.00 \mathrm{a}$ & $0.02 \pm 0.00 \mathrm{a}$ & $0.02 \pm 0.00 \mathrm{a}$ \\
\hline Linolenic (C18:3 trans) & $0.01 \pm 0.00 \mathrm{a}$ & $0.01 \pm 0.00 \mathrm{a}$ & $0.01 \pm 0.00 \mathrm{a}$ & $0.01 \pm 0.00 \mathrm{a}$ \\
\hline Total & $0.09 \pm 0.00 \mathrm{a}$ & $0.08 \pm 0.00 \mathrm{~b}$ & $0.08 \pm 0.00 \mathrm{~b}$ & $0.08 \pm 0.00 \mathrm{~b}$ \\
\hline
\end{tabular}

Different letters in row indicate significant differences by Tukey's test $(\mathrm{P}<0.05)$; Values are mean of three replicates; $S D$ : standard deviation; SFA: saturated fatty acids; MUFA: monounsaturated fatty acids; PUFA: polyunsaturated fatty acids; FC: control; FO: $5.0 \%$ golden flaxseed oil; FF: $5.0 \%$ golden flaxseed flour; FS: $5.0 \%$ golden flaxseed seed; Note: Approximately 1 g of fatty acids (of total lipids) were not identified in the analysis.

fatty acids. It is important to note that according to BRASIL (2003), all four formulations may be labeled as "zero" or "contains no" trans fat because there is less than $0.2 \mathrm{~g}$ trans fatty acid per serving.

In general, cooking increased the total concentrations of SFA, MUFA, and PUFA. The PUFA/ SFA ratio was lower in raw beef patties compared to the grilled ones. However, the n- $6 / n-3$ ratio showed the opposite pattern, which is consistent with the previous study by BILEK \& TURHAN (2009).
The recommended intake of $\alpha$-linolenic acid is $2.22 \mathrm{~g} \mathrm{day}^{-1}$, based on a diet of $2000 \mathrm{kcal} /$ day (SIMOPOULOS et al., 1999). Therefore, 100g of raw beef patties with $5.0 \%$ golden flaxseed oil provides $90.99 \%$ of the recommended daily intake of $n-3$ acid C18:3. The 5.0\% golden flaxseed flour or seed formulation provides $38.29 \%$. In contrast, control beef patties only contain $1.35 \%$ of the daily recommended value. The higher levels of n-3 PUFA are a significant contribution to a healthy diet. 
Table 4 - Profile fatty acids saturated, monounsaturated, polyunsaturated, and trans fat of grilled beef patties ( $\mathrm{g}^{100 \mathrm{~g}^{-1}}$ of product) added with golden flaxseed oil, or flour, or seed

\begin{tabular}{|c|c|c|c|c|}
\hline \multirow{2}{*}{ Parameters } & \multirow[b]{2}{*}{ FC } & \multirow[b]{2}{*}{ FO } & \multirow[b]{2}{*}{$\mathrm{FF}$} & \multirow[b]{2}{*}{ FS } \\
\hline & & & & \\
\hline Grilled product & Mean $\pm S D$ & Mean $\pm S D$ & Mean $\pm S D$ & Mean $\pm S D$ \\
\hline \multicolumn{5}{|l|}{ SFA } \\
\hline Lauric (C12:0) & $0.01 \pm 0.00 \mathrm{a}$ & $0.01 \pm 0.00 \mathrm{a}$ & $0.01 \pm 0.00 \mathrm{a}$ & $0.01 \pm 0.00 \mathrm{a}$ \\
\hline Myristic (C14:0) & $0.08 \pm 0.00 \mathrm{a}$ & $0.08 \pm 0.00 \mathrm{a}$ & $0.08 \pm 0.00 \mathrm{a}$ & $0.08 \pm 0.00 \mathrm{a}$ \\
\hline Pentadecanoic (C15:0) & $0.01 \pm 0.00 \mathrm{a}$ & $0.01 \pm 0.00 \mathrm{a}$ & $0.01 \pm 0.00 \mathrm{a}$ & $0.01 \pm 0.00 \mathrm{a}$ \\
\hline Palmitic (C16:0) & $2.24 \pm 0.01 \mathrm{~b}$ & $2.48 \pm 0.01 \mathrm{a}$ & $2.37 \pm 0.09 \mathrm{ab}$ & $2.31 \pm 0.01 \mathrm{ab}$ \\
\hline Margaric (C17:0) & $0.03 \pm 0.00 \mathrm{a}$ & $0.03 \pm 0.00 \mathrm{a}$ & $0.03 \pm 0.00 \mathrm{a}$ & $0.03 \pm 0.00 \mathrm{a}$ \\
\hline Stearic (C18:0) & $0.58 \pm 0.00 \mathrm{c}$ & $0.80 \pm 0.01 \mathrm{a}$ & $0.69 \pm 0.04 b$ & $0.70 \pm 0.00 \mathrm{~b}$ \\
\hline Arachidic (C20:0) & $0.02 \pm 0.00 \mathrm{~b}$ & $0.03 \pm 0.00 \mathrm{a}$ & $0.03 \pm 0.00 \mathrm{a}$ & $0.03 \pm 0.00 \mathrm{a}$ \\
\hline Behenic $(\mathrm{C} 22: 0)$ & $0.00 \pm 0.00 \mathrm{~b}$ & $0.01 \pm 0.00 \mathrm{a}$ & $0.01 \pm 0.00 \mathrm{a}$ & $0.01 \pm 0.00 \mathrm{a}$ \\
\hline Lignoceric (C24:0) & $0.01 \pm 0.00 \mathrm{a}$ & $0.01 \pm 0.00 \mathrm{a}$ & $0.01 \pm 0.00 \mathrm{a}$ & $0.01 \pm 0.00 \mathrm{a}$ \\
\hline Total & $2.98 \pm 0.00 \mathrm{~d}$ & $3.46 \pm 0.02 \mathrm{a}$ & $3.24 \pm 0.00 \mathrm{~b}$ & $3.19 \pm 0.00 \mathrm{c}$ \\
\hline Total percentage $(\%)$ & 47.00 & 30.03 & 38.21 & 37.84 \\
\hline \multicolumn{5}{|l|}{ MUFA } \\
\hline Palmitoleic (C16:1 n-7) & $0.05 \pm 0.00 \mathrm{~b}$ & $0.06 \pm 0.00 \mathrm{a}$ & $0.05 \pm 0.00 \mathrm{~b}$ & $0.05 \pm 0.00 \mathrm{~b}$ \\
\hline Margaroleic (C17:1 n-7) & $0.02 \pm 0.00 \mathrm{a}$ & $0.02 \pm 0.00 \mathrm{a}$ & $0.02 \pm 0.00 \mathrm{a}$ & $0.02 \pm 0.00 \mathrm{a}$ \\
\hline Oleic (C18:1 n-9) & $2.60 \pm 0.00 \mathrm{c}$ & $3.54 \pm 0.00 \mathrm{a}$ & $3.11 \pm 0.08 b$ & $3.10 \pm 0.00 \mathrm{~b}$ \\
\hline Gadoleic (C20:1 n-9) & $0.01 \pm 0.00 \mathrm{~b}$ & $0.02 \pm 0.00 \mathrm{a}$ & $0.01 \pm 0.00 \mathrm{~b}$ & $0.01 \pm 0.00 \mathrm{~b}$ \\
\hline Total & $2.68 \pm 0.00 \mathrm{c}$ & $3.64 \pm 0.00 \mathrm{a}$ & $3.19 \pm 0.05 b$ & $3.18 \pm 0.00 \mathrm{~b}$ \\
\hline Total percentage $(\%)$ & 42.27 & 31.60 & 37.62 & 37.72 \\
\hline \multicolumn{5}{|l|}{ PUFA } \\
\hline Linoleic (C18:2 n-6) & $0.63 \pm 0.07 \mathrm{c}$ & $1.43 \pm 0.90 \mathrm{a}$ & $0.95 \pm 0.01 \mathrm{~b}$ & $0.95 \pm 0.04 \mathrm{~b}$ \\
\hline$\alpha$-Linolenic (C18:3 n-3) & $0.04 \pm 0.00 \mathrm{c}$ & $2.98 \pm 0.02 \mathrm{a}$ & $1.09 \pm 0.10 \mathrm{~b}$ & $1.10 \pm 0.09 \mathrm{~b}$ \\
\hline Docosapentaenoic (DPA) (C22:5 n-3) & $0.01 \pm 0.00 \mathrm{a}$ & $0.01 \pm 0.00 \mathrm{a}$ & $0.01 \pm 0.00 \mathrm{a}$ & $0.01 \pm 0.00 \mathrm{a}$ \\
\hline Total & $0.68 \pm 0.00 \mathrm{c}$ & $4.42 \pm 0.03 \mathrm{a}$ & $2.05 \pm 0.02 b$ & $2.06 \pm 0.00 \mathrm{~b}$ \\
\hline Total percentage $(\%)$ & 10.73 & 38.37 & 24.17 & 24.44 \\
\hline \multicolumn{5}{|l|}{ Ratios } \\
\hline$n-6 / n-3$ ratio & $12.98 \pm 0.08 \mathrm{a}$ & $0.48 \pm 0.08 \mathrm{c}$ & $0.86 \pm 0.09 \mathrm{~b}$ & $0.85 \pm 0.07 \mathrm{~b}$ \\
\hline PUFA/SFA ratio & $0.23 \pm 0.05 \mathrm{c}$ & $1.28 \pm 0.02 \mathrm{a}$ & $0.63 \pm 0.04 \mathrm{~b}$ & $0.65 \pm 0.06 \mathrm{~b}$ \\
\hline \multicolumn{5}{|l|}{ Trans } \\
\hline Elaidic (C18:1 trans 9) & $0.01 \pm 0.00 \mathrm{~b}$ & $0.04 \pm 0.00 \mathrm{a}$ & $0.01 \pm 0.00 \mathrm{~b}$ & $0.01 \pm 0.00 \mathrm{~b}$ \\
\hline Linolelaidic (C18:2 trans $\mathrm{t} 9, \mathrm{t} 12)$ & $0.02 \pm 0.00 \mathrm{~b}$ & $0.03 \pm 0.00 \mathrm{a}$ & $0.02 \pm 0.00 \mathrm{~b}$ & $0.02 \pm 0.00 \mathrm{~b}$ \\
\hline Linolenic (C18:3 trans) & $0.01 \pm 0.00 \mathrm{~b}$ & $0.02 \pm 0.00 \mathrm{a}$ & $0.01 \pm 0.00 \mathrm{~b}$ & $0.01 \pm 0.00 \mathrm{~b}$ \\
\hline Total & $0.04 \pm 0.00 \mathrm{~b}$ & $0.09 \pm 0.00 \mathrm{a}$ & $0.04 \pm 0.00 \mathrm{~b}$ & $0.04 \pm 0.00 \mathrm{~b}$ \\
\hline
\end{tabular}

Different letters in row indicate significant differences by Tukey's test $(\mathrm{P}<0.05)$; Values are mean of three replicates; $S D$ : standard deviation; SFA: saturated fatty acids; MUFA: monounsaturated fatty acids; PUFA: polyunsaturated fatty acids; FC: control; FO: 5.0\% golden flaxseed oil; FF: 5.0\% golden flaxseed flour; FS: $5.0 \%$ golden flaxseed seed; Note: Approximately $1 \mathrm{~g}$ of fatty acids (of total lipids) were not identified in the analysis.

\section{CONCLUSION}

The use of golden flaxseed and derivates in beef patties is a viable technologically alternative, because the results showed that its production is possible with acceptable physico-chemical characteristics. The PUFA profile was modified, especially that of n-3 fatty acids, increasing the PUFA/SFA ratio and decreasing the $n-6 / n-3$ ratio, resulting in values closer to the optimal recommendations. Golden flaxseed flour and seed used as ingredients presented less elevated lipid content, but showed lower content of n-3 compared to the golden flaxseed oil.

\section{ACKNOWLEDGEMENTS}

The authors acknowledge the State University of the Central-West for supporting the publication of this article.

\section{REFERENCES}

ABDEL-RAHMAN, M.K. et al. Re-evaluation of individual and combined garlic and flaxseed diets on hyperlipidemic rats. 
Pakistan Journal of Nutrition, v.8, n.1, p.1-8, 2009. Available from: <http://scialert.net/abstract/?doi=pjn.2009.1.8>. Accessed: Dec 22, 2012. doi: 10.3923/pjn.2009.1.8.

ABIEC (ASSOCIAÇÃO BRASILEIRA DOS IMPORTADORES E EXPORTADORES DE CARNE). Catálogo brasileiro de cortes bovinos. Porto Alegre: Grafic-Offset, 2006. 106p.

ANSORENA, D.; ASTIASARÁN, I. Effect of storage and packaging on fatty acid composition and oxidation in dry fermented sausages made with added olive oil and antioxidants. Meat Science, v.67, n.2, p.237-244, 2004. Available from: <http://www. sciencedirect.com/science/article/pii/S030917400300278X>. Accessed: Dec 22, 2012. doi: 10.1016/j.meatsci.2003.10.011.

AOAC (ANALYSIS OF ASSOCIATION OF OFFICIAL ANALYTICAL CHEMISTS). Official Methods of Analysis of Association of Official Analytical Chemists. 3. ed. Washington D.C., 1980. 1038p.

AOCS (AMERICAN OIL CHEMIST'S SOCIETY). Official methods and recommended practices of the American oil chemist's society. 5.ed. Champaign, 2004. 1200p.

ARISSETO, A.P.; POLLONIO, M.A.R. Avaliação da estabilidade oxidativa do hambúrguer tipo calabresa, formulado com reduzidos teores de nitrito e diferentes percentagens de gordura, durante armazenamento congelado. Higiene Alimentar, v.19, n.136, p.72-80, 2005. Available from: $\quad<$ http://bases.bireme.br/cgi-bin/wxislind.exe/iah/ online/?IsisScript $=$ iah/iah. $\quad$ xis $\&$ src $=$ google $\&$ base $=$ LILACS \&lang $=\mathrm{p} \&$ nextAction $=\operatorname{lnk} \&$ exprSearch $=421578 \&$ index Sear ch=ID $>$. Accessed: Dec 22, 2012.

BARCELÓ-COBLIJN, G. et al. Gene expression and molecular composition of phospholipids in rat brain in relation to dietary n- 6 to n-3 fatty acid ratio. Biochimica et Biophysica Acta, v.1632, n.1-3, p.72-79, 2003. Available from: <http://www.sciencedirect. com/science/ article/pii/S1388198103000647>. Accessed: Dec 22, 2012. doi: 10.1016/S1388-1981(03) 00064-7.

BILEK, A.E.; TURHAN, S. Enhancement of the nutritional status of beef patties by adding flaxseed flour. Meat Science, v.82, n.4 p.472-477, 2009. Available from: <http://www. sciencedirect. com/science/article/pii/S0309174009000783>. Accessed: Nov 15, 2012. 2012. doi: 10.1016/j.meatsci.2009.03.002.

BLIGH, E.G.; DYER, W.J. A rapid method of total lipid extraction and purification. Canadian journal of biochemistry and physiology, v.37, n.8, p.911-917, 1959. Available from: <http:// www.nrcresearchpress.com/doi/abs/10.1139/059-099>. Accessed: Nov 18, 2012. doi: 10.1139/059-099.

BRASIL. ANVISA (AGÊNCIA NACIONAL DE VIGILÂNCIA SANITÁRIA). Resolução RDC no $\mathbf{3 6 0}$ : regulamento técnico sobre rotulagem nutricional de alimentos embalados de 23 de dezembro de 2003. Available from: <http://www.anvisa.gov.br/legis/resol/2003/rdc/360 03rdc.htm>. Accessed: Oct 03, 2012.

DELGADO-PANDO, G. et al. Low-fat pork liver pâtés enriched with n-3 PUFA/konjac gel: dynamic rheological properties and technological behaviour during chill storage. Meat Science, v.92, n.1, p.44-52, 2012. Available from: <http://www.sciencedirect. com/science/ article/pii/S0309174012001143>. Accessed: Dec 22 2012. doi: 10.1016/j.meatsci.2012.04. 002.
DEPARTMENT OF HEALTH. Nutritional aspects of cardiovascular disease: report on health and social subjects n.46. London: HMSO, 1994. 178p.

FERNÁNDEZ-GINÉS, J.M. et al. Meat products as functional foods: a review. Journal of Food Science, v.70, n.2, p.3743, 2005. Available from: <http://www.innofood-idi.es/ ficheros/meat_products_as_functional_foods20060429.pdf $>$. Accessed: Dec 22, 2012. doi: 10 .1111/j.1365-2621.2005. tb07110.x.

FITZPATRICK, K. North America flax facts important questions $\&$ answers for improved health and nutrition. 2.ed. Revised May 2006. Available from: <http://www. ameriflax. com/UserFiles/Image/Flax_Facts_II.pdf $>$. Accessed: Dec 23, 2012

HARTMAN, L.; LAGO, R.C.A. Rapid preparation of fatty acid methyl ester from lipids. Laboratory Practice, v.22, n.6, p.475476, 1973.

HOLLAND, B. et al. McCance and Widdowson's: the composition of foods. 5.ed. Cambridge: The Royal Society of Chemistry, 1997. 600p.

KANG, M.J. et al. The effects of polyunsaturated:saturated fatty acids ratios and peroxidisability index values of dietary fats on serum lipid profiles and hepatic enzyme activities in rats. British Journal of Nutrition, v.94, n.4, p.526-532, 2005. Available from: $<$ http://journals.cambridge.org/action/displayAbstract?fromPag $\mathrm{e}=$ online\&aid=921016 $>$. Accessed: Dec 23, 2012. doi: 10.1079/ BJN20051523.

KANG, M.J. et al. Effects of two P/S ratios with the same peroxidizability index value and antioxidants supplementation on serum lipid concentration and hepatic enzyme activities of rats. Clinica Chimica Acta, v.350, n.1-2, p.79-87, 2004. Available from: $<$ http://www.sciencedirect.com/science/article/pii/ S0009898104003341>. Accessed: Dec 22, 2012. doi: 10.1016/j. cccn.2004.07.005.

KIM Y.; ILICH, J.Z. Implications of dietary $\alpha$-linolenic acid in bone health. Nutrition, v.27, n.11-12, p.11011107 2011. Available from: <http://dx.doi.org/10.1016/j.nut. 2011.05.012>. Accessed: Dec 21, 2012. doi: 10.1016/j.nut.2011.05.012.

MARTÍNEZ, B. et al. Development of a hamburger patty with healthier lipid formulation and study of its nutritional, sensory, and stability properties. Food and Bioprocess Technology, v.5, n.1, p.200-208, 2012. Available from: <http://link.springer.com/ article/10. 1007\%2Fs11947-009-0268-x>. Accessed: Dec 23, 2012. doi: 10.1007/s11947-009-0268-X.

MERRILL, A.L.; WATT, B.K. Energy values of foods: basis and derivation. Washington, DC: USDA, 1973. (Agricultural Handbook, n.74).

MORRIS, D.H.; VAISEY-GENSER, M. Flaxseed. Encyclopedia of Food Sciences and Nutrition, v.10, n.2, p.2525-2531, 2003. Available from: <http:/www.sciencedirect.com/ science/article/ pii/B012227055X014024>. Accessed: Dec 22, 2012. doi: 10.1016/ B0-12-227055-X/01402-4.

ÖZKAN, N. et al. Combined ohmic and plate heating of hamburger patties: quality of cooked patties. Journal of Food Engineering, v.63, n.2, p.141-145, 2004. Available from: <http:// 
www.sciencedirect.com/science/article/pii/S0260877403002929>. Accessed: Dec 22, 2012. doi: 10.1016/S0260-8774(03)00292-9.

PASSOS, M.H.C.R.; KUAYE, A.Y. Influence of the formulation, cooking time and final internal temperature of beef hamburgers on the destruction of Listeria monocytogenes. Food Control, v.13, n.1, p.33-40, 2002. Available from: <http://www.sciencedirect. com/science /article/pii/S0956713501000809>. Accessed: Dec 22, 2012. doi: 10.1016/S0956-7135(01)00 080-9.

SIMOPOULOS, A.P. et al. Workshop on the essentiality of and recommended dietary intakes for omega- 6 and omega- 3 fatty acids. Journal of the American College of Nutrition, v.18, n.5, p.487489, 1999. Available from: <http://www.jacn.org/content/18/5 /487.long>. Accessed: Nov 20, 2012.

TACO (TABELA BRASILEIRA DE COMPOSIÇÃO DE ALIMENTOS). NEPA-UNICAMP. 4. ed. Campinas, São Paulo: NEPA-UNICAMP, 2011. 161p.
TRUCOM, C. A importância da linhaça na saúde. São Paulo: Alaúde, 2006. 151p

TURHAN, S. et al. Utilization of hazelnut pellicle in low-fat beef burgers. Meat Science, v.71, n.2, p.312-316, 2005. Available from: <http:/www.sciencedirect.com/science/article/ pii/ S0309174005001415>. Accessed: Dec 20, 2012. doi: 10.1016/j. meatsci.2005.03.027.

TURHAN, S. et al. Utilization of wet okara in low-fat beef patties. Journal of Muscle Foods, v.18, n.2, p.226-235, 2007. Available from: $\quad<$ http://onlinelibrary.wiley.com/doi/10. 1111/j.17454573.2007.00081.x/pdf $>$. Accessed: Dec 22, 2012. doi: 10.1111/ j.1745-4573.2007.00 081.x.

WILKES, A.P. Development trends \& technologies for formulators \& marketers. Supplement to Prepared Foods. April 2007. Available from: <http://www.flaxcouncil.ca /english/pdf/Flax $\% 20$ Supplement\%20Heart\%20Health.pdf>. Accessed: Sep 05, 2012. 